\title{
CREDIT FOR AGRICULTURAL DEVELOPMENT
}

\author{
Shahidur R. Khandker
}

Access to financial services is critical for agricultural development. By "access to financial services" we mean access to credit, savings, payments, and insurance. Such a broad measure of access is called "financial inclusion" in the recent development literature. Financial inclusion is also defined as a measure of an individual's and a business's access to use of financial services to save, borrow, make payments, and buy insurance to mitigate risk in production and consumption (Demirguc-Kunt and Klapper 2012; Demirguc-Kunt et al. 2015). ${ }^{1}$ Access to financial services facilitates an individual's and a business's day-today transactions and helps them manage everything from investment plans to unexpected emergencies. "Financial access" means access to outlets where people save, borrow, pay bills, and buy insurance, in order to initiate and expand businesses, to invest in education or health, to manage risk, and to weather shocks. All these activities induced by financial inclusion lead to higher productivity, raising income, consumption, nutrition, and education, and thus achieving multiple Sustainable Development Goals (World Bank 2018).

For good reasons policymakers thus advocate financial inclusion as a vital factor for development. The Universal Financial Access (UFA) Initiative of the World Bank stresses the need for every individual and business to have at least a transaction account with a financial institution (Demirguc-Kunt and Klapper 2012; World Bank 2018). ${ }^{2}$ A financial institution may be a bank, a microfinance institution, or a mobile financial service. A transaction account

1 "Financial inclusion" means that people have access to useful and affordable financial products and services that meet their day-to-day needs - transactions, payments, savings, credit, and insurance-delivered in a "responsible and sustainable way" (World Bank 2018).

2 As per the Global Financial Inclusion (coined as Global Findex) Survey (World Bank 2015c), "financial account" is defined as a transaction account at a bank or another type of financial institution, such as a credit union, cooperative, or microfinance institution. "Financial account" also includes a mobile money account that is limited to services that can be used without an account at a financial institution. In the Findex data the mobile money account is defined by whether the individual had used a mobile phone to pay bills or to send or receive money (Demirguc-Kunt et al. 2015). 
with any such financial institution allows people to save money as well as to send and receive payments; thus, having such a transaction account is considered a gateway to accessing other financial services such as credit and insurance. This is the underlying philosophy of the World Bank Group's Universal Financial Access 2020 initiative emphasizing every adult must have a transaction account with a financial institution. Using the Global Findex data collected by the World Bank to measure financial inclusion, it is shown that 62 percent of adults worldwide reported having an account with a financial system in 2014, compared with 51 percent found in 2011 (Demirguc-Kunt et al. 2015). Studies also find that there is almost universal financial inclusion in OECD countries ( 94 percent) but limited coverage in the developing countries ( 54 percent), varying by level of economic and financial development. ${ }^{3}$

Like any sector, access to financial services is a necessity in agriculture. More important, smallholders who cultivate more than 80 percent of land in developing countries deserve to have equal access to different types of financial services. Farmers' access to financial services helps ensure better use of resources that enhances efficiency in the use of inputs such as fertilizer, pesticides, and irrigation in production. Access to financial services also helps purchase machinery and equipment to support high-value production and crop diversification. It also helps marketing and transportation of agricultural products (Koolwal and Khandker 2018; World Bank 2015a). Access to financial services thus is critical for transforming traditional subsistence into commercialized agriculture (meaning a higher degree of market-based production).

In developing countries, agriculture is a major source of livelihood for more than 80 percent of rural people (IFC 2013). Yet access to finance (that is, credit), especially for investment in agriculture, is very limited. In Africa less than 1 percent of commercial lending goes to the agriculture sector (IFC 2013). However, unlike other sectors, financial institutions are reluctant to extend financial services in agriculture for a variety of reasons such as production risk (due to drought and excessive rainfall), lack of physical collateral (lack of title to the cultivated land), and volatility of prices due to worldwide climate changes (World Bank 2015a).

Demand for financial services in agriculture varies by degree of commercialization, size of farm holding, and level of rural development including infrastructural development. Different financial instruments (such as savings,

3 The 2017 round of the Global Findex survey shows that 69 percent of adults were found to have an account with a financial institution with 94 percent in OECD countries and 63 percent in the developing world (Demirguc-Kunt et al. 2018). This means a 7 percent increase between 2014 and 2017. 
credit, payments, and insurance) respond to different needs of actors engaged in agriculture, but the extent of financial inclusion or financial instruments available to farmers vary widely by the level of financial development, critical for agricultural development (for example, Ruete 2015). Agricultural development critically depends on financial development. However, reliable and appropriate financial instruments are only developed through financial innovations supported by government and international development agencies. A growing body of literature sheds light on the interdependence between agricultural development and financial development that is both inclusive and smallholders' friendly (for example, IFC 2013; World Bank 2015a).

Although an effective access to financial services demands access to efficient outlets for savings, borrowing, payments, and insurance, this chapter does not address farmers' needs of all categories of financial services and instruments and provisions available via a financial system. This chapter focuses only on access to credit with occasional references to other services such as savings and payments and the potential roles of governments in enhancing farmers' access to finance. Part of the fact is that access to finance is the most critical factor for agricultural development. Chapter 17 focuses on insurance to mitigate risk in agricultural production as a way to promote agricultural development.

This chapter is organized as follows. The first section discusses why agricultural credit is necessary for agricultural development. The current practices of agricultural finance with distinction between private and public sources of agricultural finance are outlined. The role of institutional finance in agricultural GDP of the developing world is examined. The chapter then highlights differential access to financial services relative to agricultural credit in selected developing countries. Successful agricultural finance practices in the developing world are discussed, to draw the conclusion that practices vary by countries even within the developing world. A review of impact studies showing how better access to financial services such as credit matters for raising agricultural productivity and hence, agricultural development, is presented. The conclusion discusses the challenges facing agricultural finance in meeting the needs of transforming traditional agriculture. It also presents a set of recommendations toward promoting agricultural development.

\section{Why Credit}

Agriculture is at a crossroads in the developing world. On the one hand, farm productivity has to be increased to support sustainable economic growth. On 
the other hand, food production has to be increased to feed a growing population, especially with a higher demand for high-valued diets such as meats, fish, and vegetables (Chapters 9-12 in this volume; FAO 2017). The global demand for food is expected to increase by 70 percent by 2050, and at least $\$ 80$ billion annual investment is necessary to meet this food demand, almost double the current investment (World Bank 2015a). But agriculture is increasingly subject to volatility of climate changes (FAO 2016). Uncertainty of harvests, input availability, and income flows have created financial constraints on agricultural producers for raising investment in agriculture.

Ironically, low-income countries, which face high climate volatility that challenges agriculture and deepens poverty (Ahmed, Diffenbaugh, and Hertel 2009), depend the most on agriculture with the lowest productivity (Figure 16.1). That is, agricultural labor productivity is inversely related to a country's agricultural share of GDP. Such inverse relationship between productivity and agriculture share in GDP is prominent in the countries of Africa south of the Sahara (SSA) and South Asia (SA). But this is not the case in economies with greater agricultural diversification and higher private investment across Europe and Central Asia (ECA), East Asia and Pacific (EAP), and Latin America and the Caribbean (LAC). As 80 percent of the farmland in Africa south of the Sahara and Asia is managed by smallholders, the burden of raising food production and farm productivity for supporting sustainable growth via raising investment rests squarely on smallholders (FAO 2012). ${ }^{4}$

The investment decisions of smallholders are nonetheless conditioned by severe financial and agroclimate environment. Farmers have been described as constrained in credit markets, often characterized by asymmetry information, adverse selection, and moral hazard of lending (Stiglitz and Weiss 1981; Guirkinger and Boucher 2008; Kumar, Turvey, and Kropp 2013). ${ }^{5}$ Financial institutions are reluctant to lend to agriculture, especially smallholders in agriculture, because of high default costs associated with high agricultural risk (due to drought, excessive rainfall, and pesticides) and high transaction costs of covering large geographical areas with poor infrastructures. For all such reasons, institutional credit is rationed; consequently, lack of credit becomes a major hurdle for undertaking investment in agriculture, let alone buying modern inputs and supporting crop diversification, key to producing high-value

4 While the interpretation of "smallholder" can vary across countries, FAO (2012) defines "smallholder" as working on up to 10 hectares.

5 In fact, studies from China and India show that binding credit constraints negatively affect food consumption and farm input applications, as well as health and educational outcomes (Kumar, Turvey, and Kropp 2013). 
FIGURE 16.1 Agricultural productivity and agricultural share of GDP, 2018

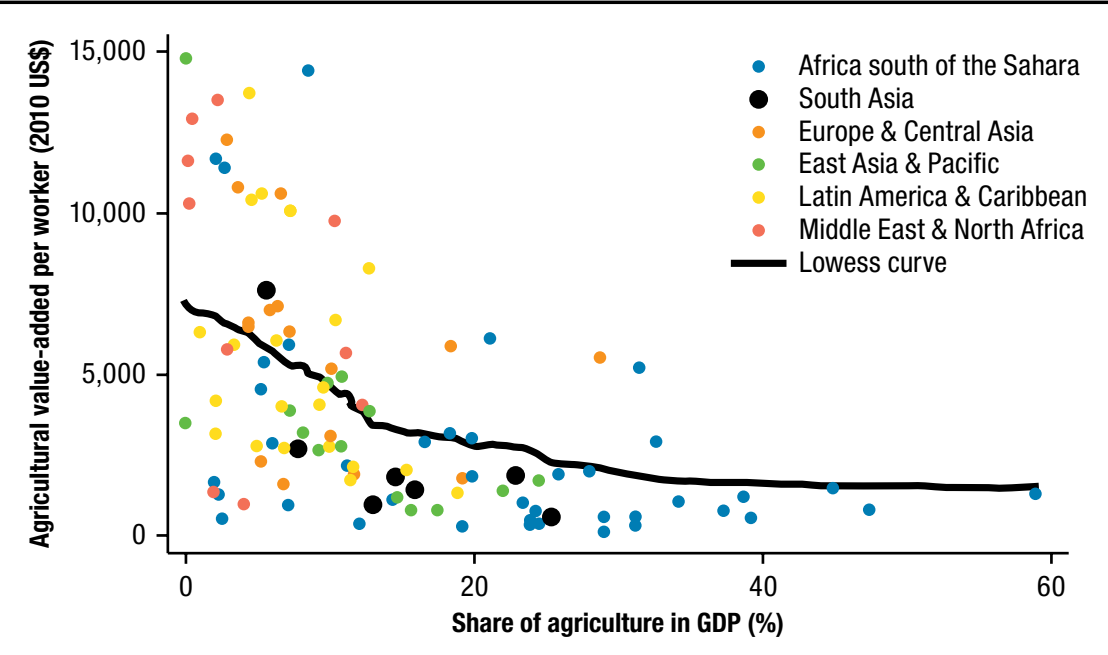

Source: Data obtained from World Bank (2019).

Note: Agriculture value-added per worker is a measure of agricultural productivity. Value-added in agriculture measures the output of the agricultural sector (ISIC divisions 1-5) less the value of intermediate inputs. Data are in constant 2010 US dollars. Regional labels and colors are used for different countries. Locally weighted regressions (bandwidth $=0.8$ ) presented along with scatterplots. Agriculture includes crop, livestock, and fishery, but the WDI data includes forestry as well from 2017 on.

cash and food crops (for example, Feder et al. 1990). Recent empirical studies in developing countries confirm that credit constraints discourage farmers from borrowing and making investments, or encourage them to finance some investments purchases with cash from nonfarm activities and crop sales (for example, Adjognon, Liverpool-Tasie, and Reardon 2017).

Deteriorating weather and climate conditions make things only harderfarmers find the income cushion insufficient for confronting agricultural risk. Rather than investing in technology to confront production uncertainty, farmers in many rural settings are increasingly engaged in nonfarm activities to smooth income and consumption (for example, Pitt and Khandker 2002; Khandker and Koolwal 2016). But rural nonfarm activities are not independent of agricultural risk. In fact, the interlinkage between farm and nonfarm production underscores the importance of raising agricultural productivity (for example, McCullough 2017; ILO 2014).

Transforming subsistence agriculture to modern agriculture needs investment in agriculture. Investment means better access to agricultural finance (both short- and long-term), which can finance investment in modern technology by smallholders. With improved access to short-term credit, for instance, 
farmers can smooth income and consumption risks, raise productivity by purchasing inputs such as high-yielding varieties and modern fertilizers, and afford improved fodder for livestock and poultry. With access to long-term credit, on the other hand, farmers can purchase or lease production machinery such as tractors or invest in improved planting and irrigation technologies for crop diversification such as high value cash crop production. Improved access to credit therefore affects not only optimal input use and improved technology adoption by releasing credit constraints but also helps farmers cope with income shocks in an uncertain agroclimate environment. This in turn helps raise farm productivity and supports a country's sustainable growth agenda.

\section{Private versus Public Sources of Agricultural Credit}

Despite efforts of governments and multilateral agencies such as the World Bank to enhance access to credit and other financial services in developing countries, about 2 billion (some 38 percent of working-age adults) worldwide have no access to institutional finance and 73 percent of poor people are unbanked (World Bank 2018a). Many of the unbanked people are smallholder farmers and landless workers.

Farmers have very limited access to institutional credit for a number of reasons. Agricultural financial markets have historically been highly regulated in developing countries (for example, subsidizing interest and input prices). Government concessional lending with below-market interest rates and loan forgiveness policies create disincentives for lending of commercial banks and the government-directed agricultural banks (for example, Adams 1988; World Bank 2015a; Seibal 2000). Financial institutions, while successfully mobilizing savings from rural areas, are reluctant to lend in agriculture for a variety of reasons such as risk in production inherent in agriculture. They restrict lending to agriculture for uncertain market price fluctuations due to agroclimate shocks. Lack of sufficient collateral of farmers is another factor underlying limited lending to agriculture. These barriers to institutional lending are compounded by a limited network of banks, making it difficult and costly for them to reach out to farmers. Banks are also not fully equipped to deal with risk and uncertainly in agriculture.

Smallholders are often not able to afford loans at terms and conditions not suitable for borrowing. One limiting factor is covariate risk, meaning borrowing and repayment do not move in the same direction - that is, farmers would like to borrow during planting season when institutions are short of loanable 
funds and pay back during harvest period (when surplus of funds available are not demanded). The standard practice of fixed repayment schedules of commercial lending is thus not always compatible with the seasonality of crop production. Farmers interested in making investment in agriculture also need long-term credit, which is not always available from financial institutions such as credit unions and microfinance institutions (MFIs).

The limited access to formal finance (including banks, credit unions, MFIs, and mobile accounts) forces many farmers to rely on own/informal finance at high cost. As per the Findex data of 2014, for example, among 58 percent of individuals (who received payments from agriculture) who borrowed, only 11 percent of them borrowed from institutional sources (Table 16.1). ${ }^{6}$ Access to formal credit varies by region-for example, some 20 percent in EAP, compared with only 7 percent in SSA. The bulk of the borrowing is reported for consumption smoothing and other purposes such as health and education-an average of 16 percent reported borrowing for farm and business purposes in the developing countries, compared with 19.8 percent in SSA and 16.7 percent in EAP. This suggests that less of borrowing goes to support agricultural production. ${ }^{7}$ This of course does not mean borrowing for consumption smoothing or supporting health expenses is unproductive, especially for those food-insecure poor farmers in developing countries whose main production factor is labor. In fact, for enhancing and securing their labor input in farming, the poor farmers use borrowing funds, in times of shortages, for consumption to sustain their labor capacity (for example, Deaton 1997; Bocher, Alemu, and Kelbore 2017; Joshi, Roy, and Sonkar 2017; Pitt and Khandker 2002). The regional differences in farmers' use of borrowing for different purposes suggests the degree of direct use of funds for farming.

Because of limited access to formal finance, farmers in developing countries rely more on informal finance for different purposes. For example, among 58 percent of farmers who borrowed in the developing world, 47 percent borrowed from informal sources (Table 16.1). Informal finance has some advantages - it has lower transaction costs and is readily available on a

6 Farmers are defined as those who sell some or all of their output in the market, who comprise the middle of the landholding distribution. Subsistence farmers, which consume most of what they produce, are not included. Sampling weights are used to make the averages representiative at the country level.

7 This does not mean that all farmers need to borrow. In fact, there are many farmers who save and therefore need a safe outlet for savings on a regular basis (for example, Zeller and Sharma 2000). But the point is that like other sectors, better acess to institutional finance for both shortand long-term credit is essential for supporting agricultural development with diffusion of modern technology and crop diversification. 
TABLE 16.1 Access to institutional finance by region, 2014

\begin{tabular}{|c|c|c|c|c|c|c|c|c|}
\hline \multirow[b]{2}{*}{ Region } & \multicolumn{4}{|c|}{ Received agricultural payments } & \multicolumn{4}{|c|}{ Did not receive agricultural payments } \\
\hline & $\begin{array}{l}\text { Has an } \\
\text { account } \\
(\%)\end{array}$ & $\begin{array}{l}\text { Borrowed in } \\
\text { the } \\
\text { past year* }(\%)\end{array}$ & $\begin{array}{c}\text { Borrowed } \\
\text { for farm/ } \\
\text { business } \\
(\%)\end{array}$ & $\begin{array}{l}\text { Obser- } \\
\text { vations }\end{array}$ & $\begin{array}{l}\text { Has an } \\
\text { account } \\
(\%)\end{array}$ & $\begin{array}{c}\text { Borrowed in } \\
\text { the } \\
\text { past year* }(\%)\end{array}$ & $\begin{array}{c}\text { Borrowed } \\
\text { for farm/ } \\
\text { business } \\
(\%)\end{array}$ & $\begin{array}{l}\text { Obser- } \\
\text { vations }\end{array}$ \\
\hline EAP & 58.8 & $53.6(19.6)$ & 16.7 & 3,851 & 64.5 & $42.8(14.3)$ & 6.7 & 9,353 \\
\hline ECA & 40.8 & $51.2(14.9)$ & 8.8 & 3,889 & 54.1 & $36.7(12.5)$ & 2.4 & 22,153 \\
\hline LAC & 47.3 & $52.2(19.2)$ & 18.5 & 1,357 & 45.1 & $36.6(12.6)$ & 6.3 & 16,679 \\
\hline MENA & 30.4 & $54.8(6.6)$ & 9.2 & 702 & 25.2 & $40.3(6.8)$ & 4.1 & 7,363 \\
\hline SA & 41.6 & $50.3(10.5)$ & 13.0 & 2,375 & 40.3 & $38.8(6.9)$ & 5.3 & 6,757 \\
\hline SSA & 29.3 & $65.0(6.9)$ & 19.8 & 11,749 & 30.3 & $45.7(5.5)$ & 7.4 & 22,295 \\
\hline $\begin{array}{l}\text { Developing } \\
\text { world }\end{array}$ & 38.3 & $58.4(11.4)$ & 16.4 & 23,923 & 43.7 & $40.2(10.0)$ & 5.4 & 84,600 \\
\hline
\end{tabular}

Source: World Bank (2015c).

Note: * Figures in parentheses show percentage of borrowing from formal sources.

1. Having an account indicates either institutional financial account, or mobile money account, or both.

2. EAP = East Asia and Pacific, ECA = Europe and Central Asia, LAC $=$ Latin America and Caribbean, MENA = Middle East and North Africa, SA = South Asia, SSA = Africa south of the Sahara. Developing world excludes OECD countries.

3. Sampling weights used. About 21.81 percent of individuals affirmatively responded to the question "if received agricultural payments in last 12 months."

short-term notice. But informal financing often at short-terms is insufficient to enable farmers to access modern technologies, fertilizer, irrigation, and other inputs (World Bank 2015a). Informal finance also has limits in leveraging resources or pooling risks, as informal finance is provided by village-level lenders who are normally associated with the same covariate risk that affects farmers. These limits are costly to small farmers in diversifying agriculture, undertaking investments, and assuming risks for growing high-valued crops, meats, and vegetables. Agricultural-led growth needs long-term investment in farming and agribusinesses for marketing high-valued crops and farm products. The resources for such investments would come only from financial institutions such as banks.

But commercial banks lend a small share of portfolio to agriculture compared with agriculture's share of GDP. In 2015 agriculture accounted for 27.5 percent of GDP and received only 5.1 percent of commercial lending in SSA (Figure 16.2). Consequently, agricultural lending of commercial banks accounted for 7 percent of agricultural GDP in 2000 and 9 percent in 2015 in SSA (Figure 16.3). In contrast, in EAP with more developed agriculture, agricultural credit of commercial banks accounted for 13 percent in 2000 and 47 percent of agricultural GDP in 2015. 


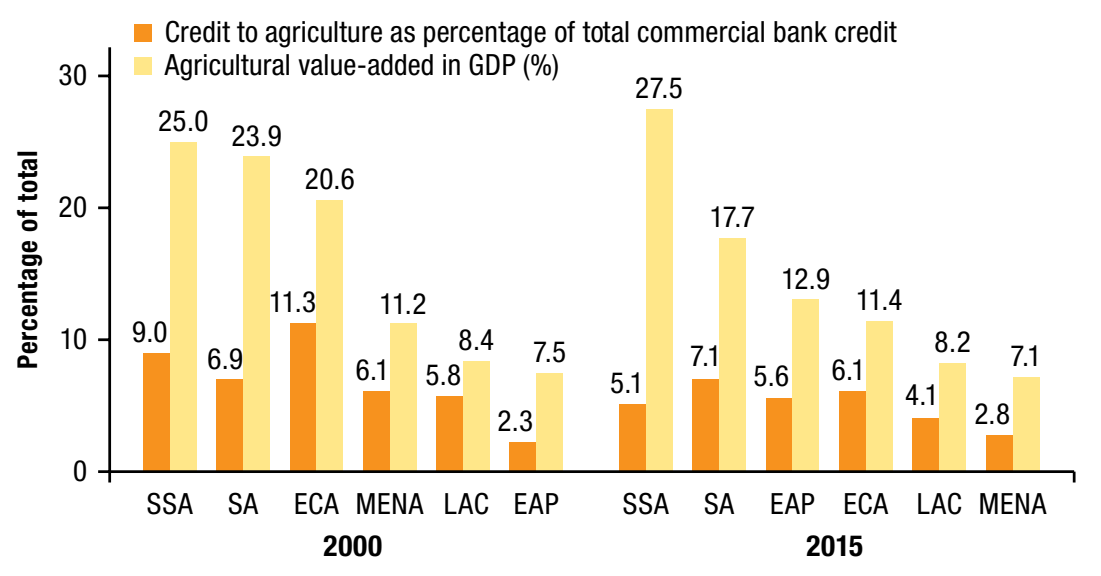

Source: Data from World Bank (2019).

Note: Sample size 127. EAP = East Asia and Pacific, ECA = Europe and Central Asia, LAC = Latin America and Caribbean, MENA = Middle East and North Africa, SA = South Asia, SSA = Africa south of the Sahara.

FIGURE 16.3 Agricultural credit as share of agricultural GDP, 2000 and 2015

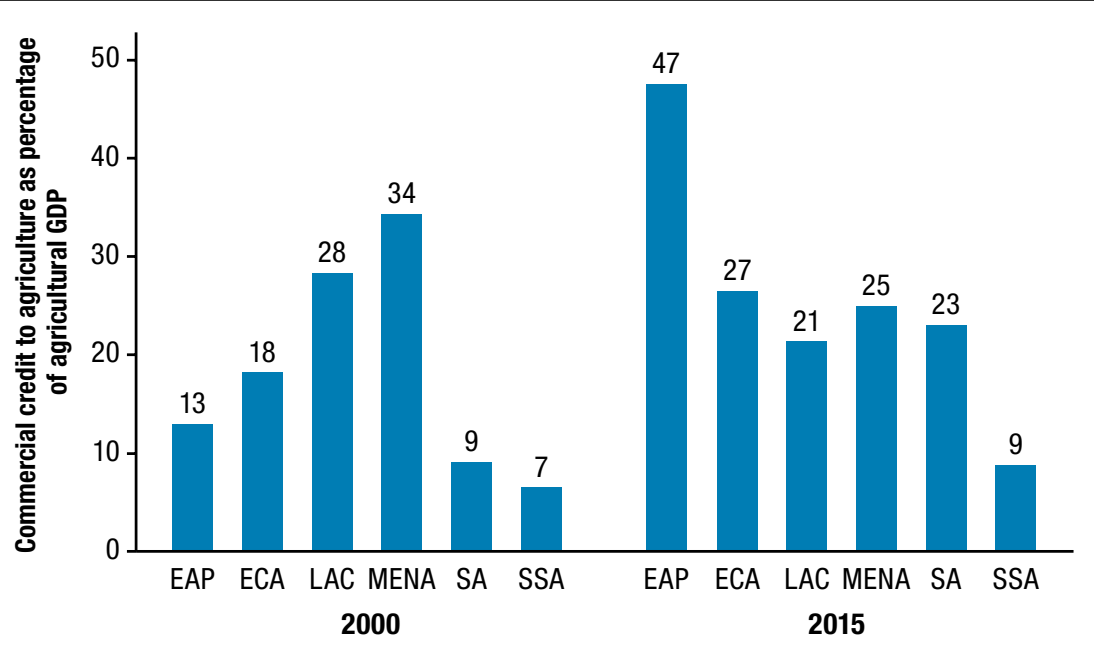

Source: Data from World Bank (2019).

Note: Sample size 117. EAP = East Asia and Pacific, ECA = Europe and Central Asia, LAC = Latin America and Caribbean, MENA = Middle East and North Africa, SA = South Asia, SSA = Africa south of the Sahara. 


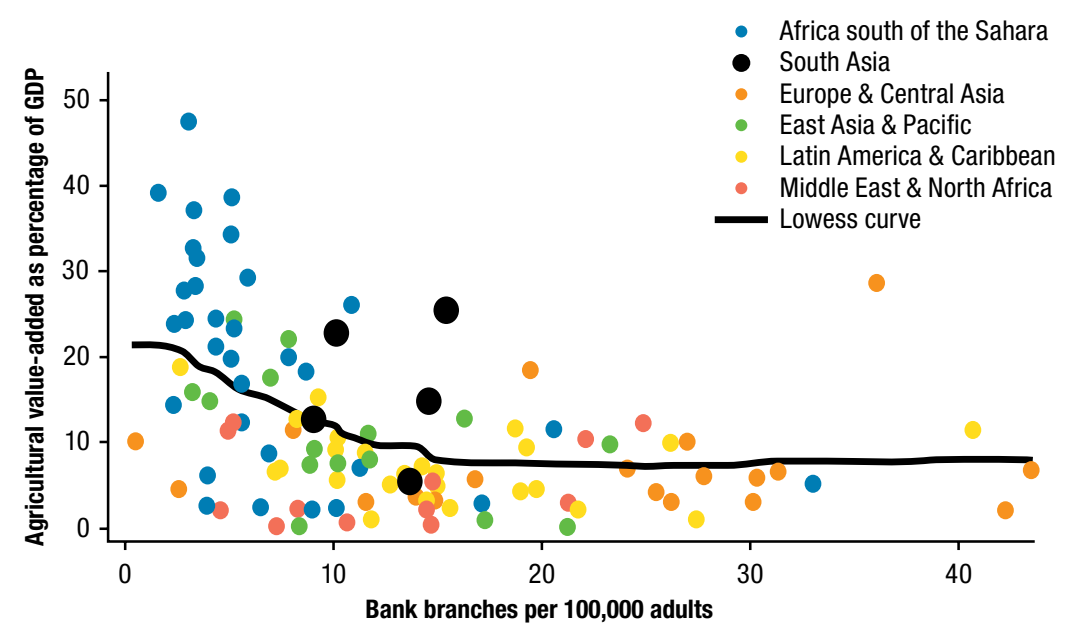

Source: World Bank (2019).

Commercial banks played a bigger role in agricultural development of EAP relative to SSA and SA regions. Limited commercial lending to agriculture is a direct outcome of an inverse relationship between the extent of per capita commercial bank branches and share of agricultural GDP in a country's total GDP (Figure 16.4). We see fewer commercial bank branches per capita with high share of agriculture GDP in total GDP. Of course, commercial banks are not the only provider of institutional credit. There are other sources of institutional credit such as MFIs, agricultural development banks, agricultural cooperatives, and registered credit unions and/or rotating societies for credit and savings (RoSCAS). Yet all these institutions together do not account for more than 11 percent of farm-sector lending. ${ }^{8}$

However, mobile financial services (MFS) are increasingly providing financial services such as payments and transfer of remittance. But MFS hardly extends credit and therefore has not much impact on agricultural investment. Consequently, the role of financial institutions (banks, microfinance institutions, and mobile networks) in agriculture is limited, especially in SSA and SA, where the need for institutional credit is the highest for promoting agricultural investment and productivity.

8 See discussion below with reference to Table 16.1. 


\section{Current State of Agricultural Finance in Developing Countries}

Borrowing is only one measure of access to financial services. As indicated earlier, a broad measure of financial access is defined by financial inclusion, which is defined as a measure of an individual's and a business's access to and use of financial services to save, borrow, make payments, and manage risk in production and consumption (Demirguc-Kunt and Klapper 2012; DemirgucKunt et al. 2015). Using the Global Findex data of 2014, we can present the degree of financial inclusion among farmers and nonfarmers in both developed and developing countries.'

Financial inclusion among farmers (those who received income from agriculture over the past 12 months) in the developing world (excluding OECD countries) was 38.3 percent, meaning only 38 percent of farmers had an account with a financial system in 2014 (see Table 16.1). Interestingly, among the 38 percent of those who have a financial account, only 11 percent borrowed from institutional sources. This means some 27 percent of farmers in the developing world use financial services for other purposes such as savings, payments, and remittances. Financial inclusion in agriculture varies by region-it is highest among farmers in EAP (58.8 percent) and lowest in SSA (29.3 percent). Borrowing from financial institutions is the highest in EAP and LAC regions and the lowest in MENA and SSA regions. Such variations are due to varying financial practices and policies. Consider financial inclusion in a few selected countries to understand why financial inclusion matters for agricultural lending for investment. Among the selected seven countries, Thailand from EAP perhaps has the best practices of financial services-some 87 percent of Thai farmers have an account with a financial institution, which is close to the average of OECD countries ( 94 percent), higher than the EAP average ( 58.8 percent), and even higher than the average of the developing world (38.3 percent) (Table 16.2).

In contrast, Viet Nam has only 28.9 percent financial inclusion among farmers, much lower than the EAP average but close to the average of the SSA region (29.3 percent). In SA, India has 60.6 percent coverage, higher than the SA average of 41.6 percent, while Bangladesh's coverage of 31.4 percent

9 In its 2014 round the Global Financial Inclusion Survey (also called Global Findex survey) asked individuals whether they received any payments for the sale of agricultural products. "Farmers" are defined as those who received payments from the sale of agricultural products. Consequently, the definition of being a farmer is restricted to those involved in marketbased agriculture rather than in agriculture purely for own consumption (Koolwal and Khandker 2018). 


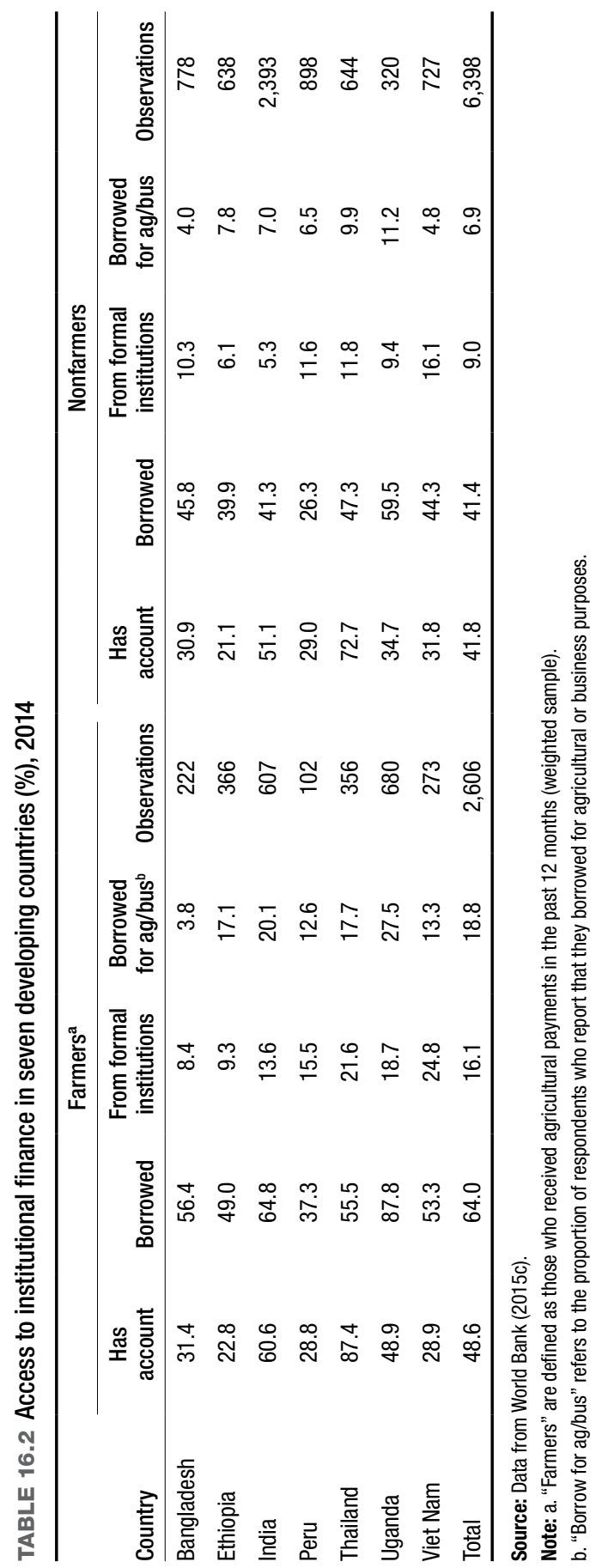


is lower than the SA average. Uganda is an outlier in SSA, as its financial inclusion for farmers is 48.9 percent, compared with the SSA average of 29.3 percent and 22.8 percent average in Ethiopia, the lowest among the seven countries considered. Uganda also has the highest rate of borrowing among the seven countries-18.7 percent of farmers borrowed from financial institutions and 27.5 percent of the borrowing was for agricultural purposes. Bangladesh has the lowest (3.8 percent) and Uganda has the highest coverage (27.5 percent) of institutional borrowing for agriculture.

Low rates of financial inclusion in agriculture rest on the following factors: (1) the transaction costs of rural financial intermediation are high due to poor infrastructures and need of small loans and savings to cover a wide geographical areas; (2) high default costs of lending due to problems of loan enforcement and frequent loan forgiveness policies of the government; and (3) reluctance of banks and other financial institutions to lend money to farmers because of perceived high risks associated with agriculture in terms of weather uncertainty and production risks (World Bank 2015a). Rather than facilitating rural financial intermediation, governments often create obstacles such as interest caps and concessional lending for banks to operate efficiently for agricultural lending.

\section{Examples of Agricultural Credit and Microcredit Programs}

Because of the importance for extending credit to smallholders, governments with the help of the World Bank and other agencies are supporting banks and microfinance institutions (MFIs) to extend credit to agriculture and operate efficiently in rural settings. The agencies' credit access includes extending agricultural credit directly to local banks, which then provide loans to farmers and rural entrepreneurs. Prior to the 1990s, the World Bank and other multilateral institutions managed the disbursement of agricultural finance directly through project implementation units (World Bank 2003). However, in recent years banks provide lines of credit to financial institutions to extend credit. Examples of recent World Bank-supported credit access programs include the Rural Finance Project in Viet Nam, the SAGARPA Program in Mexico, the Financial Services for the Poorest Project in Bangladesh, and programs to provide local financial institutions technology upgrades and training in other countries (for example, Strengthening India's Rural Credit Cooperatives Project and Ghana Rural Financial Services Project). In 2014 the World Bank financed a nongovernment microfinance facility called the 
Bandhan to become a rural bank to support rural lending, including agricultural lending (World Bank 2015b). Commercial bank lending to agriculture has somewhat improved in recent years for such initiatives but is not enough to enhance agricultural investment to support agricultural development.

Similarly, microfinance institutions in developing countries have no doubt made some headway in reaching small and marginal farmers with finance of donors to resolve supply-side credit constraints (for example, Khandker, Khalily, and Samad 2017). MFIs have nonetheless been promoting rural nonfarm activities in developing countries to generate additional income and employment for marginal farmers. However, MFIs have limited capacity to extend farm lending because they typically lack required licenses to operate as a bank like the Bandhan Bank of India or Grameen Bank of Bangladesh that can mobilize savings. Yet many of these microfinance institutions refrained from offering a wide array of financial products to suit the needs of farmers and small producers. As a result, microfinance institutions have tended to operate on a small scale, offering local, demand-driven options, such as group-liability for short-term lending, to better reach clients and improve their own profitability and sustainability.

Nonetheless, microfinance has been lending increasingly to support agriculture, given that many small and marginal farmers are willing to participate in MFI programs to support income earning activities, including farming. MFI share of agriculture is rising over time, based on the demand for credit in agricultural production to meet high demand for food and other staples. Microfinance institutions are also encouraged to extend seasonal credit, sometimes with funds of commercial banks to satisfy their government-set target to reach farmers in their loan portfolio (Khandker, Samad, and Badruddoza 2018).

The limit of higher MFI lending to agriculture, even if it is successful in many countries in reaching marginal and small farmers, is that they have failed to support long-term investment in agriculture necessary for raising agricultural productivity. Take the cases of two countries-Bangladesh and Thailand-with the deliberate policies to expand both microfinance and bank lending to agriculture. Bangladesh's agricultural development banks and commercial banks, including nationalized commercial banks (NCBs), have been lending increasingly in rural areas. ${ }^{10}$ Lending to smaller farmers is a relatively recent phenomenon, handled by microfinance agencies such as

10 Bangladesh's banking sector is dominated by four state-owned NCBs, which control approximately half the assets in the banking sector. 
Grameen Bank, the Association for Social Advancement (ASA), and BRAC. Palli Karma-Sahayak Foundation (PKSF), Bangladesh's wholesale microfinance lending facility, recently started a Seasonal Loans and Agricultural Lending program, nearly doubling the funds it directs toward crop agriculture (Khandker, Samad, and Badruddoza 2018). Yet its agricultural portfolio is less than 15 percent of total portfolio.

With such recent efforts, banks (both commercial and agricultural development banks) lent 7.2 percent of their total lending to agriculture, and microfinance institutions, including the famous Grameen Bank, lent about 39.5 percent of their lending to agriculture. However, they together lent only 11.2 percent of total institutional credit disbursed in 2015. Bangladesh's wholesale microfinance agency's total annual portfolio was about US\$2 billion of which agricultural lending was no more than 12 percent in 2015. In the same year, while agricultural share of GDP was about 16 percent in Bangladesh, agricultural lending was about 11 percent of total institutional lending. While total institutional lending accounts for 42 percent of the GDP, agricultural credit provided by institutions explains 31 percent of the agricultural GDP (Khandker, Samad, and Badruddoza 2018). Although MFIs are increasingly financially solvent, agricultural development banks are highly subsidized.

In contrast, Thailand's specialized agricultural bank, known as the Bank for Agriculture and Agricultural Cooperatives (BAAC), provides half of agricultural loans, while the microfinance facility known as Thai Village Fund (TVF), the largest MFI in the world, provides 29.2 percent of its portfolio for agricultural purposes (Haughton, Khandker, and Torero 2018). Together they accounted for 10.5 percent of all loans (which is 13.5 percent) that went to agriculture in 2013. BAAC accounted for 6.6 percent (which was 51 percent of the total BAAC loan advanced), while TVF accounted for only 3.9 percent (which was 29 percent of the total TVF loan advanced) of total loans received by agriculture. While agriculture accounts for 8.4 percent of GDP, institutional credit in Thailand explained some 81 percent of total credit received by agriculture of which 30 percent hailed from microfinance institutions. So the bulk of agricultural loans comes from the BAAC. Although both institutions are government-owned and -supported, TVF is highly subsidized and the BAAC is not (Haughton, Khandker, and Torero 2018).

One common parameter for both countries is, however, that the agricultural portfolio of financial institutions is low-11.1 percent in Bangladesh and 13.5 percent in Thailand, although agricultural GDP in Thailand is almost 10 times Bangladesh's agricultural GDP. But Thailand's agriculture 
is funded more by an agricultural development bank (BAAC) rather than microfinance institutions such as TVF, while the opposite is the case for Bangladesh. MFI lending to agriculture in Bangladesh is largely short-term, such as seasonal crop loans or annual general loans. Seasonal or annual loans are important for crop production as well as income and consumption smoothing. But long-term loans are necessary for promoting large investment to commercialize and diversify crops in agriculture. It is no wonder that agricultural productivity is much higher in Thailand (largely because of diversification from cereal production to rubber and sugar production) than Bangladesh (predominantly cereal production). In 2014 agricultural valueadded per worker (in constant 2010 US\$) was US\$715 in Bangladesh compared with US\$2,133 in Thailand. ${ }^{11}$ Higher productivity in Thailand must be an outcome of modern technology diffusion for high-value crop production and agro-based processing with private investment in agriculture and agribusinesses (Haughton, Khandker, and Torero 2018).

Mobile financial services (MFS) are the latest innovative way of extending financial services to agriculture. Mobile phones are ubiquitous in many countries and increasingly in developing countries. In 2017 there were more than 1.5 billion cellular subscriptions in South Asia and 764 million in Africa south of the Sahara (World Bank 2018b). Mobile money is a prominent innovation emerging from widespread mobile phone use, and it enables owners to deposit, transfer, and withdraw funds without physically going to a bank or owning a bank account. While MFS have transaction fees, they reduce costs for some transactions, including those geographically disparate and those where opportunity cost of holding cash may be high, as in high-crime cities (Economides and Jeziorski 2015).

Mobile financial services are more easily accessible than traditional financial institutions and are also associated with lower costs of managing financial instruments (Suri 2017). As of 2017, the mobile money industry processes a billion dollars a day with 690 million registered accounts globally (GSMA 2018). In particular, MFS could play an important role in addressing the fixed costs of managing financial instruments, which often constrain the ability of formal banks to provide financial services to the poor in general and smallholders in particular. However, as the data shows, there is no overwhelming evidence of achieving this end using this means by commercial banks

11 In contrast, rice yield per hectare in the same year was 46,188 kilograms per hectare in Bangladesh and 29,118 kilograms per hectare in Thailand. This suggests that short-term credit must play a more important role in producing rice (a short-term cereal crop) in Bangladesh than in Thailand. 
in extending credit services to smallholders, although MFS has successfully helped achieve higher financial inclusion by providing financial services other than credit.

Mobile phones are in fact widespread in emerging and developing economies, although there is significant variation in the use of mobile financial services across countries and sectors, as well as extending financial services. Using the Findex data of 2014, we see that mobile financial services accounted for 11.7 percent of financial accounts across the developing world with the highest ( 15.9 percent) in SSA, explaining 54 percent of financial accounts, and lowest in ECA ( 0.5 percent), explaining only 0.5 percent of financial accounts (Table 16.3). While banks and MFIs need physical infrastructure to support financial inclusion, MFS does not find this as a barrier. However, MFS is not reaching farming communities equally. While 79 percent of financial accounts are facilitated by mobile network in Uganda, MFS is nonexistent in Ethiopia; 22.8 percent of financial inclusion in Ethiopia is facilitated by banks and microfinance institutions, compared to only 10.2 percent in Uganda. Branch networks are therefore the single most effective way of reaching farmers in a more developed agricultural economy. For instance, in Thailand, while 87 percent of individuals in agriculture have an account with a financial institution that is entirely facilitated by banks and MFIs, only 1.6 percent of financial inclusion is facilitated via mobile financial services.

A mobile financial account often provides financial services such as payments and transfer of remittance, but it is not yet capable of extending credit or mobilizing savings. In Uganda, for example, although financial inclusion is high ( 48.9 percent), mainly facilitated by mobile phone network, the extent of borrowing from financial institutions to support agriculture is negligible. Thus, while 87.8 percent of the Ugandans (who received payment from agriculture) have borrowed, only 18.7 percent of them borrow from financial institutions, leaving the remaining 69 percent to borrow from informal sources (see Table 16.2). Moreover, only 27.5 percent of the loans are meant for agriculture. This shows that even if financial inclusion is high in Uganda mostly because of having a transaction account with mobile financial services, the extent of borrowing from institutional services is highly limited and thus farmers rely on noninstitutional sources.

Financial inclusion via mobile financial services is nonetheless worth supporting. Mobile finance can reduce reliance on cash transactions, and time burdens for those living in more geographically isolated areas with less access to transport, financial institutions, and infrastructure. In Kenya, Uganda, and other countries, mobile money accounts are increasingly being developed to 
TABLE 16.3 Access to mobile account, 2014 (\%)

\begin{tabular}{|c|c|c|c|c|c|c|}
\hline \multirow[b]{2}{*}{ Region } & \multicolumn{3}{|c|}{ Farmers $^{\mathrm{a}}$} & \multicolumn{3}{|c|}{ Nonfarmers } \\
\hline & $\begin{array}{l}\text { Any financial } \\
\text { account }\end{array}$ & $\begin{array}{l}\text { Mobile } \\
\text { account }\end{array}$ & (\%) & $\begin{array}{l}\text { Any financial } \\
\text { account }\end{array}$ & $\begin{array}{l}\text { Mobile } \\
\text { account }\end{array}$ & $(\%)$ \\
\hline \multicolumn{7}{|l|}{ By region $^{b}$} \\
\hline EAP & 58.8 & 5.2 & 8.8 & 64.5 & 3.2 & 5.0 \\
\hline ECA & 40.8 & 0.2 & 0.5 & 54.1 & 0.5 & 0.9 \\
\hline LAC & 47.3 & 5.4 & 11.4 & 45.1 & 1.8 & 4.0 \\
\hline MENA & 30.4 & 1.7 & 5.6 & 25.2 & 0.7 & 2.8 \\
\hline SA & 41.6 & 3.1 & 7.5 & 40.3 & 1.6 & 4.0 \\
\hline SSA & 29.3 & 15.9 & 54.3 & 30.3 & 9.4 & 31.0 \\
\hline Total & 38.3 & 11.7 & 30.5 & 43.7 & 4.6 & 10.5 \\
\hline \multicolumn{7}{|c|}{ By seven developing countries ${ }^{c}$} \\
\hline Bangladesh & 31.4 & 1.9 & 6.1 & 30.9 & 2.9 & 9.4 \\
\hline Ethiopia & 22.8 & 0.0 & 0.0 & 21.1 & 0.0 & 0.0 \\
\hline India & 60.6 & 3.7 & 6.1 & 51.1 & 2.0 & 3.9 \\
\hline Peru & 28.8 & 0.0 & 0.0 & 29.0 & 0.0 & 0.0 \\
\hline Thailand & 87.4 & 1.4 & 1.6 & 72.7 & 1.3 & 1.8 \\
\hline Uganda & 48.9 & 38.7 & 79.1 & 34.7 & 27.1 & 78.1 \\
\hline Viet Nam & 28.9 & 0.4 & 1.4 & 31.8 & 0.5 & 1.6 \\
\hline Total & 48.6 & 11.0 & 22.6 & 41.8 & 2.6 & 6.2 \\
\hline
\end{tabular}

Source: Data from World Bank (2015c).

Note: a. "Farmers" are defined as those who "received agricultural payments in the past 12 months" (weighted sample). b. EAP = East Asia and Pacific, ECA = Europe and Central Asia, LAC = Latin America and the Caribbean, MENA = Middle East and North Africa, $S A=$ South Asia, $S S A=$ Africa south of the Sahara.

c. "Developing world" excludes OECD countries.

link farmers, agents, and buyers (for example, Kikulwe, Fischer, and Qaim 2014). Mobile-based financial services are emerging to draw a greater share of the population into formal financial services (not necessarily for borrowing but for payment services and remitting money), particularly in Africa south of the Sahara and other regions. But mobile financial services are not yet found to be an effective mechanism for extending credit to small farmers in areas where institutional credit is highly due but not currently available.

But this does not mean that MFS cannot offer financial services that can extend credit and mobilize savings using the concept of branchless banking. In principle, mobile money can serve as a facilitator to bring financial services to the doorsteps of smallholders, where users can display some financial track record through financial transactions. Using such records, financial 
institutions can develop credit scores of potential customers (via reduction of information asymmetries), upon which they can extend credit through reducing transaction costs as well as the costs of managing these financial accounts. However, evidence so far does not lend support to rising expected lending portfolios for farmers via this method of banking. Thus, further innovations are warranted in promoting linkages of mobile financial services with agricultural finance and how such linkage can be facilitated by the government and international development agencies to promote digitation in agrifinance.

\section{Impact of Agricultural Credit on Smallholders' Income and Productivity}

Estimating the effect of credit or financial access is necessary for determining whether institutional credit matters, how it matters, and what it means to policymaking. More specifically, estimating credit effect is a way to understand the mechanisms in which provision of credit through financial institutions is a prudent policy for boosting agricultural investment and productivity for supporting the government agenda of growing sustainably and attaining food security.

\section{Evidence of Potential Role of Financial Inclusion in Agriculture}

Agricultural productivity (measured by agricultural valued-added per worker) at the country level is found to have the strongest positive correlation with access to financial institutions (either measured by account ownership, commercial bank branches, or agricultural credit as a share of total institutional credit). Figure 16.5 shows that a country's share of agricultural GDP is positively associated with the share of agricultural credit in total credit disbursed, meaning that the higher the share of lending to agriculture via financial institutions, the higher is the share of agricultural GDP. Similarly, as Figure 16.6 shows, a country's agricultural productivity is positively associated with the country's number of commercial bank branches. This suggests that availability of banks increases the chances of borrowing for agricultural investment and the induced effects on agricultural productivity. ${ }^{12}$

Figure 16.7 shows the trend in financial account ownership against agricultural value-added per worker as a measure of agricultural productivity. Thus

12 Availability of a bank branch also increases savings mobilization from rural areas, which in turn can help smooth farmers' income and consumption, thereby ensuring a higher liquidity in absorbing risks in production. 


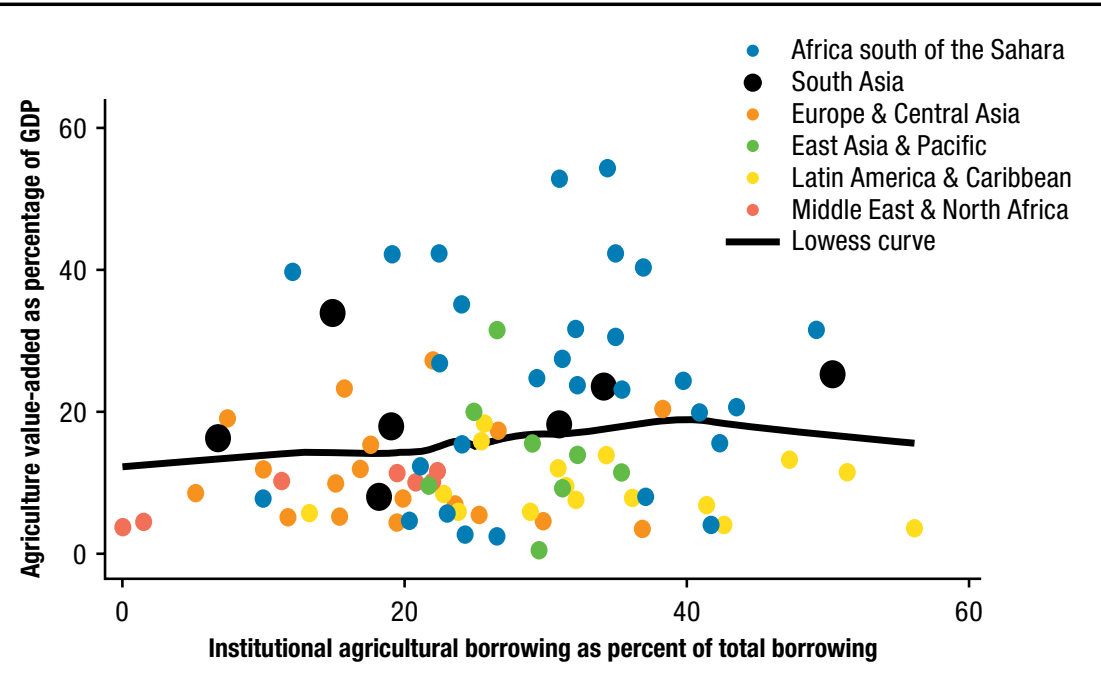

Source: World Bank (2015c) and World Bank (2019).

Note: Agricultural borrowing is measured in the following manner: (1) From FINDEX data, we first selected all the individuals who received agricultural payments in the past 12 months. (2) Among those individuals, we observed whether the individual borrowed (of any kind) in the past 12 months. (3) Those who mentioned the purpose of borrowing as farm/business are considered to have agricultural borrowing, which implies the percentage of sampled individuals who borrowed for agricultural/ business purposes who also received agricultural payment in the past 12 months.

FIGURE 16.6 Growth in agricultural productivity by growth in bank branches, 2018

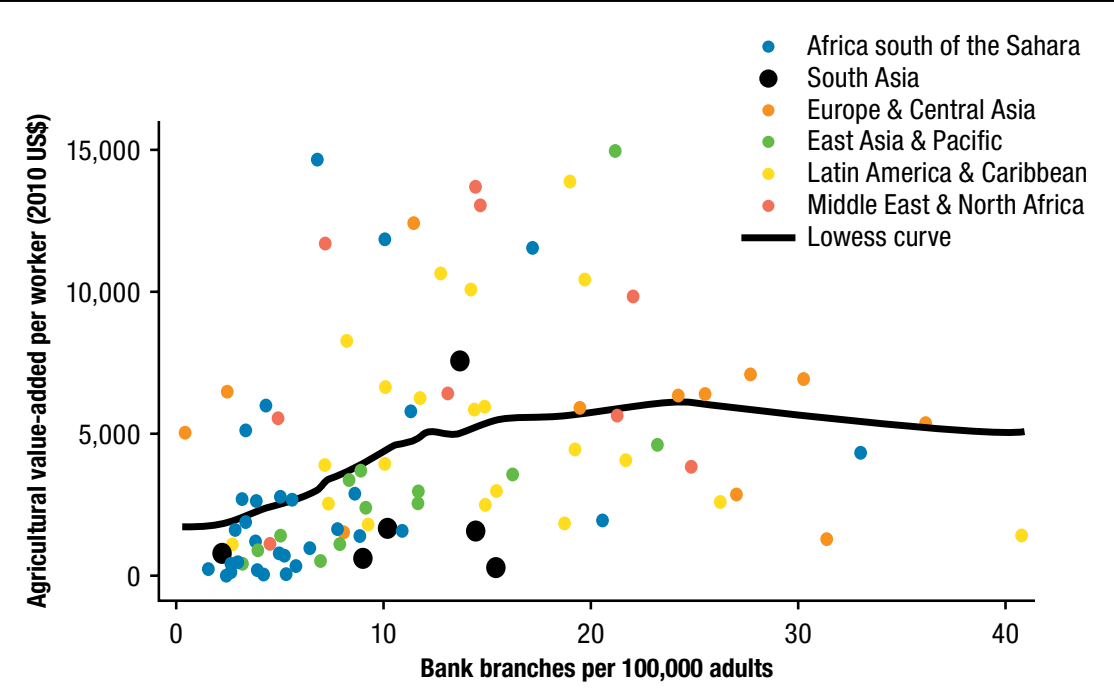

Source: Global Findex data; World Bank (2019). 
FIGURE 16.7 Financial account ownership against agricultural productivity (country agriculture value-added per worker), 2014

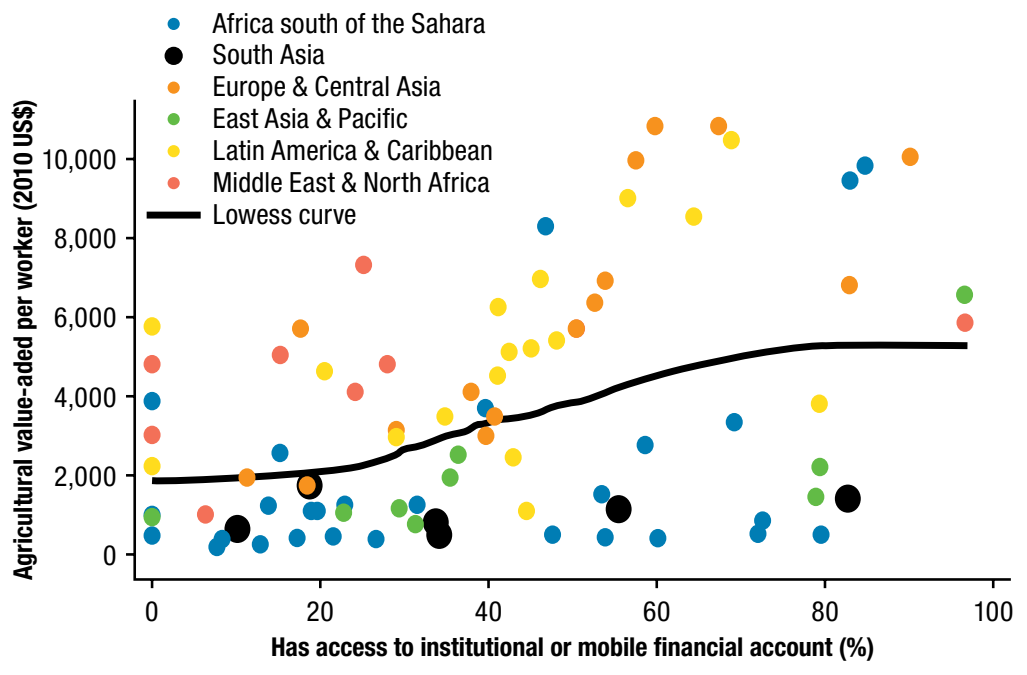

Source: World Bank (2015c; 2019).

financial inclusion (measured broadly in terms of having an account with a financial institution or mobile financial service) is higher among countries with a higher index of agricultural productivity than countries with lower agricultural productivity. That is, increasing the level of financial inclusion in agriculture can lead to raising agricultural productivity, investment, food production, and food security. These relations are simple correlations but do not necessarily mean causality, meaning that there is a potential role of financial services in raising agricultural productivity, but it is not clear if financial inclusion actually increases productivity or if higher productivity raises demand for financial services. Disentangling this relationship is a causality question-what would have happened if credit access were not improved? Identification of the causal effect of credit is a challenge that involves understanding how improved access and use of specific services affects productivity.

\section{Evidence of the Causal Effect of Agricultural Credit}

Measuring the causal effect of financial service is a major goal of any study on credit policy for agricultural development. However, establishing causalitythat is, identifying the net effect of financial access-is difficult because agricultural development outcomes can be affected by the same factors that affect farmers' decisions to borrow from financial institutions. This is the classic 
problem of endogeneity that needs to be resolved satisfactorily to estimate the causal effect of credit.

In theory, credit access does not seem to affect agricultural productivity unless farmers are liquidity constrained (for example, Feder et al. 1990; Karlan et al. 2014). When farmers are liquidity constrained, they are under a constrained decision-making regime in which credit access does directly affect agricultural decision-making processes such as input use and farming practices. Even with a credit-constrained regime, it does not necessarily follow without further assumptions that credit induces an effect on agricultural outcomes such as productivity, as borrowing decisions are not determined independently of agricultural productivity. The endogeneity issue involves estimating the demand for credit as part of a farmer's investment decision and its consequential impact on agricultural productivity. Various methods (for example, randomized controlled trial, propensity score matching, and instrumental variable) can help resolve the problem of endogeneity in estimating credit effects (for details, see Khandker, Koolwal, and Samad 2010).

Studies using alternate methods have shown that financial inclusion has positive effects on income, productivity, consumption, education, health, gender equality, and other indicators of well-being (for example, Cull, Ehrbeck, and Holle 2014; Aker et al. 2014; Klapper, El-Zoghbi, and Hess 2016). In particular, financial inclusion can help mitigate risks in production through enhanced investment and reduced costs of easing credit constraints in production. A large body of literature suggests that higher access to and use of financial services by farmers can help increase modern use of inputs and technology, and investment in agriculture, leading to higher farm productivity and income and hence improved household welfare (for example, Feder et al. 1990; Cull, Ehrbeck, and Holle 2014; Karlan et al. 2014).

Assuming credit access is measured by bank branch density, several studies have found that access to commercial and agricultural banks has created viable alternatives to moneylenders for households with somewhat greater assets and collateral. For example, Binswanger and Khandker (1995) found that better access to farm credit provided by banks spurred fertilizer use and investment in agriculture; however, it is less successful in generating viable institutions to generate agricultural employment. But bank density increases agricultural investment and productivity in India via investment in pump set, a very productive tool for raising agricultural output. Rural bank branches increase nonfarm employment and rural wages (Binswanger, Khandker, and Rosenzweig 1993). Rural bank branch expansion, savings mobilization, and credit disbursement are all found to increase farm and nonfarm output 
significantly and hence reduce rural poverty consequently (for example, Burgess and Pande 2005; Prina 2015; Brune et al. 2016).

Recent efforts on identifying the effect of farm credit include microdata studies that attempt to identify the extent of credit constraint faced by farmers and its induced effect on productivity. This is because of the fact that credit effect depends on the extent of credit constraint encountered by farmers (for example, Feder et al. 1990). Studies from Peru show that credit constraints lower the value of agricultural output substantially for poor households; however, for those households without credit constraints, productivity is independent of such endowments as land and liquidity (Boucher, Guirkinger, and Trivelli 2009; Guirkinger and Boucher 2008). Some other studies also confirm that credit constraints affect agricultural output and productivity (Feder et al. 1990; Sial and Carter 1996), farm profit (Carter 1989; Foltz 2004), and farm investment (Carter and Olinto 2003). The presence of credit constraint among MFI borrowers also matters in raising farm incomethe effect of borrowing on farm income is higher for credit-constrained than noncredit-constrained borrowers (Khandker, Khalily, and Samad 2016).

Farmers face risks such as unpredictable weather and crop price variation, affecting how they choose to borrow and invest. Thus smoothing consumption across seasons is an important motivation for microfinance participation in Bangladesh (Pitt and Khandker 2002; Khandker 2012). The enhanced ability to smooth consumption permits households to choose riskier but higher-yielding contracts in agricultural markets (Pitt 2000). Although microfinance has traditionally been targeted toward the nonfarm sector, because of the linkages across farm and nonfarm sectors and funds are fungible, it nonetheless promotes farm income growth (Khandker, Khalily, and Samad 2016).

Several studies examined the effect on household consumption and income risk by credit when credit is obtained through mobile money accounts. Access to mobile money services (for example, remittances) reduces transaction costs of money transfer as well as consumption risks, thereby increasing consumption and reducing poverty (Jack and Suri 2014, 2016). Among the most successful mobile money products, M-PESA in Kenya, launched in 2007, now has virtually universal coverage in the country. Suri (2017) reviewed the impacts of M-PESA on responses to a range of outcomes and finds users spend more on medical expenses after a health shock while also increasing expenses on food and maintaining education expenditures. Moreover, mobile money contributed to a decline in poverty rate by 2 percentage points as a result of better access to mobile money services and thus increased household consumption and savings. 
Several other studies, using experimental methods, have evaluated the impacts of rural farmers' improved access to credit. In Morocco, Crepón and others (2011) found that the effects of rural expansion of microfinance institutions depend on activities that households are initially involved in, particularly self-employed agriculture-a large increase in sales and profits leads to substantial increases in expenditure and employment. Karlan et al. (2014) used an experimental design of a combination of cash grants to test the relevance of imperfect credit and an incomplete insurance market to agricultural investment and productivity in Nigeria. They found that an incomplete insurance market, which protects farm income from perceived agricultural risk, is more binding than a liquidity (that is, credit) constraint for promoting investment in agriculture. ${ }^{13}$

Banerjee, Karlan, and Zinman (2015) reviewed randomized controlled trials measuring the impact of MFI access across countries; the review revealed that microfinance access improved business activity, ranging from investments, business size, and profits, by at least a marginal extent across the six countries examined. However, the extent and type of impacts varied across countries. In India, small business investment and profits of preexisting businesses increased, but consumption did not significantly increase (Banerjee et al. 2015). In Ethiopia, Tarozzi, Desai, and Johnson (2015) find no treatment effect for the majority of outcomes. A joint liability microcredit program for women had a positive impact of access to group loans on female entrepreneurship and household food consumption but not on total working hours or income in the household in Mongolia (Attanasio et al. 2015). Angelucci, Karlan, and Zinman (2015), however, do not find transformative impacts on many outcomes in a clustered randomized trial in Mexico.

Although microfinance institutions have scope to improve credit access to agriculturalists and rural people, the evidence is not definitive on whether microfinance alleviates poverty and what exactly are its impacts on business activity. In investigating the question of external validity-concerns the studies may be too different from each other to generalizable their resultsMeager (2019) aggregates evidence from seven randomized controlled trials and finds negligible impact of microfinance access on household business and consumption variables, and that this impact is unlikely to be transformative.

13 This of course does not mean that liquidity (and hence, credit) is not a binding constraint for smallholders in agriculture. This study observes that when an insurance market is missing in a risky environment, lack of insurance is perhaps more binding than a liquidiy constraint for raising farm investment and productivity. 
Indeed, these experimental studies are not conclusive. Methods also matter in evaluating microfinance. Experimental methods are usually applied to evaluate a short-term program (usually less than 18 months of intervention) such as PROGRESA in Mexico-a conditional cash transfer (Angrist et al. 2002; de Janvry et al. 2006; Schultz 2004). In contrast, microfinance or institutional finance for that matter, is not a cash transfer, and accrued benefits from self-employed activities supported under microfinance require a certain minimum length of exposure (for example, a minimum of three years of exposure means an experimental method is inappropriate). Therefore, nonexperimental methods, in contrast to experimental methods, are used to explore the impact of certain length of program exposure. Many nonexperimental studies of microfinance are found to have substantive positive contribution of microfinance in enhancing income, consumption, and poverty reduction (for example, Islam 2011; Imai, Arun, and Annim 2010; Imai et al. 2012; Pitt and Khandker 1998; Khandker 2005: Khandker, Khalily, and Samad 2016). It is thus important to distinguish between short-term versus long-term impacts of microfinance and draw complementarity between these alternative methods. Further studies are necessary to reconcile the findings drawn from alternative methods of impact evaluation regarding roles of microfinance in development (Wydick 2016). It is important to carry out more studies to demonstrate how a microfinance facility works and helps smallholders and poor farmers to avert the short-term and long-term consequences of exposures to climate and other risks increasingly associated with smallholder farming.

Enhancing profitability of smallholder agriculture is the prime goal associated with the agenda of growing sustainably and attaining food security. Smallholders are not, however, a homogeneous group; some smallholder farmers have the potential to increase farm profits and undertake commercial activities in the agricultural sector, while others should be supported in exiting agriculture and seeking nonfarm opportunities. For smallholder farmers with profit potential, their ability to be successful is apparently hampered by challenges including limited financial inclusion. By overcoming this and other challenges, such as climate change and price shocks, smallholders can move from subsistence to commercially oriented agricultural systems and increase their profits (Fan et al. 2013). However, a major knowledge gap exists as to whether and how an improvement in financial access can help increase profitability of smallholders. We do not know if providing credit alone is sufficient to improve profitability. It is indeed possible that other innovative financial products are necessary that provide additional services using new technologies 
so that actors in the agri-value chain can make better profit-enhancing investments.

\section{Challenges and Recommendations to Support Innovations in Agricultural Credit}

Agricultural investment is absolutely necessary to raise food production and farm productivity, especially in smallholder agriculture, to support a country's agenda of growing sustainably and attaining food security. Access to finance is thus critical to promote investment in agriculture and hence agricultural growth and productivity. However, farming in developing countries, where agricultural growth is the driver of growth and development, is managed largely by smallholders. Smallholders in agriculture need funds to invest but for a variety of reasons are constrained in accessing finance, especially institutional finance. Although access to financial services such as savings, credit, payments, and insurance is limited in general in rural areas, smallholders are limited further in accessing finance for reasons such as high transaction costs of small loans and savings, high risk associated with farming caused by drought and excessive rains, and lack of appropriate policies facilitating coverage of the financial services provided by a country's financial institutions.

Evidence suggests that institutional credit plays an important role in enhancing investment and productivity in smallholder agriculture. Better access to institutional credit is desirable because it is less expensive compared to own or informal finance to buy fertilizer, irrigation, and other productivityenhancing inputs to raise farm productivity. Credit also helps resolve cash flow problems of crop production and mitigate risks in farming due to uncertainty of weather patterns and climate changes. Provision of weather-indexed insurance helps farmers also mitigate risks, but credit at easy terms with lower transaction costs to support investments can mitigate agricultural risk effectively. Institutional credit, especially long-term, encourages private investment in marketing and agro-processing, and thus helps produce high-valued crops, meat, and vegetables. Diversification, modernization, and commercialization of agriculture are the hallmarks of agricultural development for attaining sustainable growth and food security.

However, financial institutions, especially agricultural development banks and commercial banks, are not capable of serving the smallholder agriculture sustainably and effectively. Banks have been asked to support subsidized credit in many low-income countries but have failed to support profitably government credit schemes. In the process, however, many of them have failed 
miserably not only to support agricultural credit extension but also to become self-sustainable institutions. Agricultural finance institutions must learn how to serve farmers as per demand and deliver products profitably to resolve both short-term cash flow problems and long-term investment needs of smallholders. Institutions must be developed to address idiosyncratic and systematic risks that characterize agriculture in a highly volatile agroclimate environment. Government policies must be facilitating rather than dictating institutional lending to enhance private investment in agriculture. Governments must refrain from directing misguided credit policies and programs, which are found to stifle growth and sustainability of financial institutions.

A variety of bilateral and nongovernmental organization-funded programs have recently evolved to provide various options to the challenging task of extending credit and other financial services to farmers, especially among smallholders in Africa and Asia (for example, Kloeppinger-Todd and Sharma 2010). For example, to address limited collateral among smaller farmers, techniques have been developed to tailor lending strategies to the agricultural supply chain. Thus farmers can borrow against output stored in licensed warehouses, or producers and processors can make binding contracts for crop output after which processors repay the producer's loan to the bank. Other alternatives being used include direct product-distribution channels (for example, mobile banking), electronic point-of-sale devices (for example, those run by the Uganda Microfinance Union in rural areas), and partnerships with market-facilitating institutions. Also, as is discussed in Chapter 17, agricultural insurance (for example, weather-indexed insurance) is an emerging policy area for helping farmers to manage production and investment risks (Cai 2012; Giné and Yang 2009).

Government can help develop alternative institutions with appropriate incentive structures for agricultural development; a combination of bank finance, microfinance, and mobile finance is perhaps necessary for successful agro-based lending and other financial services. One group of finance may not fit the various needs of farmers. Examples of Thailand's BAAC and India's Bandhan Bank are perhaps instructive for other countries to follow (World Bank 2015b). ${ }^{14}$ They show how an agricultural development bank with a mandate to support agriculture or a nongovernment microfinance facility in a rural setting-both of them relying entirely on donor funds and not permitted or encouraged to mobilize savings — can be turned into a viable financial

14 Another example is Indonesia's Bank Rakayat Indonesia (BRI), which had gone through reforms for several years before it became a self-sustainble agricultural development bank (Seibel 2000). 
institution that is now allowed to mobilize savings and able to meet the banking needs of farmers and other small rural producers. In the absence of the large-scale government subsidies/donor funding of the past, policymakers may facilitate the institutions to explore ways of expanding financial access to smallholders effectively and sustainably.

Governments may support innovations in how to develop the facilitating role of financial institutions in enhancing smallholders' access to finance. They need to provide a sound macroeconomic and regulatory framework, a prudent monitoring framework through central banks to protect savers, and fund innovations in financial product design and diversification via experimentation. Learning from microfinance institutions and informal finance to use social collateral may be a way to mitigate risk in rural lending and should be part of innovation in agricultural finance. Institutional innovation may also promote linkages between formal financial institutions and microfinance institutions, rotating savings and credit associations (RoSCAS), and village banks. In short, governments should support innovations and institutional development but never subsidize interest rates on lending to support agricultural finance. After all, government support is to be directed toward lowering transaction costs of banking for the poor smallholders to access financial services such as credit. This is perhaps the only way for any government to support agricultural finance that is institutionally viable as well as effective in enhancing agricultural investment in support of agricultural development.

\section{References}

Adams, D. W. 1988. "The Conundrum of Successful Credit Projects in Floundering Rural Financial Markets." Economic Development and Cultural Change 36 (2): 355-367.

Adjognon, S. G., L.S.O. Liverpool-Tasie, and T. Reardon. 2017. "Agricultural Input Credit in Sub-Saharan Africa: Telling Myth from Facts.” Food Policy 67: 93-105.

Ahmed, S. A., N. S. Diffenbaugh, and T. W. Hertel. 2009. "Climate Volatility Deepens Poverty Vulnerability in Developing Countries.” Environment Research Letters 4 (034004).

Aker, J., R. Boumnijel, A. McClelland, and N. Tierney. 2016. "Payment Mechanisms and AntiPoverty Programs: Evidence from a Mobile Money Cash Transfer Experiment in Niger." Economic Development and Cultural Change 65 (1): 1-37.

Angelucci, M., D. Karlan, and J. Zinman. 2015. "Microcredit Impacts: Evidence from a Randomized Microcredit Program Placement Experiment by Compartamos Banco." American Economic Journal: Applied Economics 7 (1): 151-182. 
Angrist, J., E. Bettinger, E. Bloom, E. King, and M. Kramer. 2002. "Vouchers for Private Schooling in Colombia: Evidence from a Randomized Natural Experiment." American Economic Review 92 (5): $1535-1558$.

Attanasio, O., B. Augsburg, R. De Haas, E. Fitzsimons, and H. Harmgart. 2015. "The Impacts of Microfinance: Evidence from Joint-Liability Lending in Mongolia." American Economic Journal: Applied Economics 7 (1): 90-122.

Banerjee, A., E. Duflo, R. Glennerster, and C. Kinnan. 2015. “The Miracle of Microfinance? Evidence from a Randomized Evaluation." American Economic Journal: Applied Economics 7 (1): 22-53.

Banerjee, A., D. Karlan, and J. Zinman. 2015. “Six Randomized Evaluations of Microcredit: Introduction and Further Steps." American Economic Journal: Applied Economics 7 (1): 1-21.

Binswanger, H., and S. R. Khandker. 1995. "The Impact of Formal Finance on the Rural Economy of India." Journal of Development Studies 32: 234-262.

Binswanger, H., S. Khandker, and M. Rosenzweig. 1993. "How Infrastructure and Financial Institutions Affect Agricultural Output and Investment in India." Journal of Development Economics 41: 337-466.

Bocher, T., B. Alemu, and Z. Kelbore. 2017. “Does Access to Credit Improve Household Welfare? Evidence from Ethiopia Using Endogenous Regime Switching Regression." African Journal of Economic and Management Studies 8 (1): 51-65.

Boucher, S., C. Guirkinger, and C. Trivelli. 2009. "Direct Elicitation of Credit Constraints: Conceptual and Practical Issues with an Application to Peruvian Agriculture." Economic Development and Cultural Change 57 (4): 609-640.

Brune, L., X. Giné, J. Goldberg, and D. Yang. 2016. "Facilitating Savings for Agriculture: Field Experimental Evidence from Malawi." Economic Development and Cultural Change 64 (2): $187-220$.

Burgess, R., and R. Pande. 2005. "Do Rural Banks Matter? Evidence from the Indian Social Banking Experiment." American Economic Review 95 (3): 780-795.

Cai, J. 2012. "Social Networks and the Decision to Insure: Evidence from Randomized Experiments in China." Working Paper, University of California, Berkeley.

Carter, M. R. 1989. "The Impact of Credit on Peasant Productivity and Differentiation in Nicaragua." Journal of Development Economics 103: 13-36.

Carter, M. R., and P. Olinto. 2003. "Getting Institutions Right for Whom? Credit Constraints and the Impact of Property Rights on the Quantity and Composition of Investment." American Journal of Agricultural Economics 85 (1): 173-186. 
Crepón, B., F. Devoto, E. Duflo, and W. Pariente. 2011. "Impact of Microfinance in Rural Areas of Morocco: Evidence from a Randomized Evaluation." MIT Working Paper, Massachusetts Institute of Technology, Cambridge, MA.

Cull, R., T. Ehrbeck, and N. Holle. 2014. "Financial Inclusion and Development: Recent Impact Evidence." CGAP Focus Note 92. World Bank, Washington, DC.

Deaton, A. 1997. The Analysis of Household Surveys: A Microeconometric Approach to Development Policy. Baltimore: Johns Hopkins University for the World Bank.

de Janvry, A., F. Finan, E. Sadoulet, and R. Vakis. 2006. "Can Conditional Cash Transfer Programs Serve as Safety Nets in Keeping Children at School and from Working When Exposed to Shocks?" Journal of Development Economics 79 (2): 349-373.

Demirguc-Kunt, A., and L. Klapper. 2012. "Measuring Financial Inclusion: The Global Findex Database.” Policy Research Working Paper 6025. World Bank, Washington, DC.

Demirguc-Kunt, A., L. Klapper, D. Singer, S. Ansar, and J. Hess. 2018. The Global Findex Database 2017: Measuring Financial Inclusion and the Fintech Revolution. Washington, DC: World Bank.

Demirguc-Kunt, A., et al. 2015. "The Global Findex Data Base 2014: Measuring Financial Inclusion around the World." Policy Research Working Paper 7255. World Bank, Washington, DC.

Economides, N., and P. Jeziorski. 2015. “Mobile Money in Tanzania." Working Paper. New York University, New York.

Fan, S., J. Brzeska, M. Keyzer, and A. Halsema. 2013. From Subsistence to Profit: Transforming Smallholder Farms. Food Policy Report. Washington, DC: International Food Policy Research Institute.

FAO (Food and Agricultural Organization of the United Nations). 2012. "Smallholders and Family Farmers." Sustainability Pathways, Smallholders. Rome.

- 2016. Climate Change and Food Security: Risks and Responses. Rome.

- 2017. The State of Food Security and Nutrition in the World 2017: Building Resilience for Peace and Food Security. Rome.

Feder, G., L. J. Lau, J. Y. Lin, and X. Luo. 1990. “The Relation between Credit and Productivity in Chinese Agriculture: A Model of Disequilibrium." American Journal of Agricultural Economics 72 (5): 1151-1157.

Foltz, J. 2004. "Credit Market Access and Profitability in Tunisian Agriculture." Agricultural Economics 30: 229-240.

Giné, X., and D. Yang. 2009. "Insurance, Credit, and Technology Adoption: Field Experimental Evidence from Malawi." Journal of Development Economics 89: 1-11. 
GSMA (Group System Mobile Association). 2018. 2017 State of the Industry Report on Mobile Money. London.

Guirkinger, C., and S. Boucher. 2008. "Credit Constraints and Productivity in Peruvian Agriculture." Agricultural Economics 39: 295-308.

Haughton, J., S. Khandker, and M. Torero. 2018. “Agricultural Finance in Thailand.” Mimeo. Washington, DC.

IFC (International Finance Corporation). 2013. "IFC and Agri-Finance: Creating Opportunity Where It's Needed Most." Washington, DC.

ILO (International Labour Organization). 2014. "Economic Diversification of the Rural Economy." Decent Work in the Rural Economy Policy Guidance Notes. Geneva.

Imai, K. S., T. Arun, and S. K. Annim. 2010. "Microfinance and Household Poverty Reduction: New Evidence from India." World Development 38 (12): 1760-1774.

Imai, K. S., R. Gaiha, G. Thapa, and S. K. Annim. 2012. "Microfinance and Poverty Reduction: A Macro Perspective." World Development 40 (8): 1675-1689.

Islam, A. 2011. "Medium and Long-Term Participation in Microcredit: An Evaluation Using a New Panel Dataset from Bangladesh." American Journal of Agricultural Economics 93 (3): $847-866$.

Jack, W., and T. Suri. 2014. "Risk Sharing and Transactions Costs: Evidence from Kenya’s Mobile Money Revolution.” American Economic Review 104 (1): 183-223.

_. 2016. “The Long-Run Poverty and Gender Impacts of Mobile Money." Science 354 (6317): $1288-1292$.

Joshi, P. K., D. Roy, and V. K. Sonkar. 2017. “Elements of Agriculture Value Chain Financing: A Review." In Financing Agriculture Value Chains in India: Challenges and Opportunities, edited by G. Mani, P. K. Joshi, and M. V. Ashok. Part 1, Agriculture Value Chain Financing: Theoretical Framework, Chapter 2, 15-32. Singapore: Springer.

Karlan, D., R. Osei, I. Osei-Akoto, and C. Udry. 2014. "Agricultural Decisions after Relaxing Credit and Risk Constraints." Quarterly Journal of Economics 129 (2): 597-652.

Khandker, S. 2005. "Microfinance and Poverty: Evidence Using Panel Data from Bangladesh.” World Economic Review 19 (2): 263-286.

- 2012. "Seasonality of Income and Poverty in Bangladesh." Journal of Developmental Economics 97: 244-256.

Khandker, S., B. Khalily, and H. Samad. 2016. Beyond Ending Poverty: The Dynamics of Microfinance in Bangladesh. Washington, DC: World Bank.

Khandker, S., and G. Koolwal. 2016. "How Has Microcredit Supported Agriculture? Evidence Using Panel Data from Bangladesh.” Agricultural Economics 47 (2): 157-168. 
Khandker, S., G. Koolwal, and H. Samad. 2010. Handbook on Impact Evaluation: Quantitative Methods and Practices. Washington, DC: World Bank.

Khandker, S., H. Samad, and S. Badruddoza. 2018. “Agricultural Finance in Bangladesh.” Mimeo. Washington, DC.

Kikulwe, E., E. Fischer, and M. Qaim. 2014. "Mobile Money, Smallholder Farmers, and Household Welfare in Kenya." PLoS ONE 9 (10): e109804.

Klapper, L., M. El-Zoghbi, and J. Hess. 2016. “Achieving the Sustainable Development Goals: The Role of Financial Inclusion." Consultative Group to Assist the Poorest (CGAP), World Bank, Washington, DC.

Kloeppinger-Todd, R., and M. Sharma. 2010. Innovations in Rural and Agricultural Finance. Washington, DC: IFPRI and World Bank.

Koolwal, G., and S. Khandker. 2018. "Financial Inclusion in Agriculture across Countries: An Overview and Descriptive Analysis using the Global Findex.” Mimeo. Washington, DC.

Kumar, C., C. Turvey, and J. Kropp. 2013. “The Impact of Credit Constraints on Farm Households: Survey Results from India and China." Applied Economic Perspectives and Policy 35(3): 508-527.

McCullough, E. B. 2017. "Labor Productivity and Employment Gaps in Sub-Saharan Africa." Food Policy 67: 133-152.

Meager, R. 2019. "Understanding the Average Impact of Microcredit Expansions: A Bayesian Hierarchical Analysis of Seven Randomized Experiments.” American Economic Journal: Applied Economics 11 (1): 57-91.

Pitt, M. 2000. "The Effect of Nonagricultural Self-Employment Credit on Contractual Relations and Employment in Agriculture: The Case of Microfinance Programs in Bangladesh.” Bangladesh Development Studies (June-September): 15-48.

Pitt, M., and S. Khandker. 1998. “The Impact of Group-Based Credit Programs on Poor Households in Bangladesh: Does Gender of Program Participants Matter?” Journal of Political Economy 106: 958-996.

- 2002. "Credit Programs for the Poor and Seasonality in Rural Bangladesh." Journal of Development Studies 39 (2): 1-24.

Prina, S. 2015. "Banking the Poor Via Savings Accounts: Evidence from a Field Experiment." Journal of Development Economics 115 (C): 16-31.

Ruete, M. 2015. "Financing for Agriculture: How to Boost Opportunities in Developing Countries." Investment in Agriculture Policy Brief 3, International Institute for Sustainable Development (IISD). 
Schultz, T. P. 2004. "School Subsidies for the Poor: Evaluating the Mexican PROGRESA Poverty Program." Journal of Development Economics 74 (1): 199-250.

Seibal, H. D. 2000. “Agricultural Development Banks: Close Them or Reform Them." Finance and Development 37 (2).

Sial, M. H., and M. R. Carter. 1996. "Financial Market Efficiency in an Agrarian Economy: Microeconometric Analysis of the Pakistani Punjab." Journal of Development Studies 32 (5): 771-798.

Stiglitz, J., and A. Weiss. 1981. "Credit Rationing in Markets with Imperfect Information.” American Economic Review 71 (3): 393-410.

Suri, T. 2017. “Mobile Money." Annual Review of Economics 9: 497-520.

Tarozzi, A., J. Desai, and K. Johnson. 2015. “The Impacts of Microcredit: Evidence from Ethiopia." American Economic Journal: Applied Economics 7 (1): 54-89.

World Bank. 2003. “Review of the Bank’s Rural Finance Experience.” Working Paper, Operations Evaluation Department. World Bank, Washington, DC.

_.2015a. "Agricultural Finance." Washington, DC. www.worldbank.org/en/topic/ financialsector/brief/agriculture-finance.

_.2015b. “Bandhan Becomes India’s Youngest Bank.” World Bank News, August 23.

_.2015c. Databank: Global Financial Inclusion (database). https://databank.worldbank.org/ reports.aspx? source $=1228$

_. 2018a. "UFA2020 Overview: Universal Financial Access Initiative 2020.” www.world bank.org/en/topic/financialinclusion/brief/achieving-universal-financial-access-by-2020.

_.2018b. "Financial Inclusion: An Overview.” www.worldbank.org/en/topic/financial inclusion/overview.

_.2019. “World Development Indicators." https://data.worldbank.org/indicator/IT.CEL SETS.

Wydick, B. 2016. "Microfinance on the Margin: Why Recent Impact Studies May Understate Average Treatment Effects." Journal of Development Effectiveness 8: 257-265.

Zeller, M., and M. Sharma, 2000. "Many Borrow, More Save, and All Insure: Implications for Food and Microfinance Policy.” Food Policy 25: 143-167. 
